\title{
ACT-Rによる内発的動機づけのモデル化 パターンマッチングに基づく知的好奇心のメカニズム*1
}

\section{Modeling Intrinsic Motivation in ACT-R}

\author{
Mechanism of Intellectual Curiosity based on Pattern Matching
}

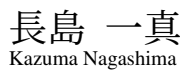 \\ 静岡大学大学院総合科学技術研究科 \\ Shizuoka University \\ nagashima.kazuma.16@shizuoka.ac.jp \\ 森田 純哉
Junya Morita \\ （同上） \\ j-moritadinf.shizuoka.ac.jp, https://acml-shizuppi.net/ \\ 竹内 勇剛 \\ （同上） \\ takeuchi@inf.shizuoka.ac.jp, http://cog.cs.inf.shizuoka.ac.jp
}

keywords: cognitive modeling, ACT-R, intrinsic motivation, intellectual curiosity

\section{Summary}

To date, many studies concerned with intrinsic motivation in humans and artificial agents based on a reinforcement learning framework have been conducted. However, these studies have rarely explained the correspondence between intrinsic motivation and other essential cognitive functions. This study aims to build a method to express curiosity in new environments via the ACT-R (Adaptive Control of Thought-Rational) cognitive architecture. To validate the effectiveness of this proposal, we implement several models of varying complexity using the method, and we confirm that the model's behavior is consistent with human learning. This method focuses on the " production compilation" and "utility" modules, which are generic functions of ACT-R. It regards pattern matching with the environment as a source of intellectual curiosity. We prepared three cognitive models of path planning representing different levels of thinking. We made them learn in multiple-breadth maze environments while manipulating the strength of intellectual curiosity, which is a type of intrinsic motivation. The results showed that intellectual curiosity in learning an environment negatively affected the model with a shallow level of thinking but was influential on the model with a deliberative level of thinking. We consider the results to be consistent with the psychological theories of intrinsic motivation. Furthermore, we implemented the model using a conventional reinforcement learning agent and compared it with the proposed method.

\section{1.はじめに}

人間の活動を駆動する報酬は様々である．金銭，地位 などのように外部から与えられる報酬もあれば，その活 動を行うこと自体の楽しさなど，内的に生じる欲求や感 情そのものが報酬となることもある. 後者の報酬は内発 的動機づけと呼ばれ, 前者の外発的動機づけに対して, 持続的で高いレベルの学習に寄与するとされる. 近年で はこの考えを援用し, 内発的動機づけの一種である好奇 心に注目した強化学習の研究が進められており, 特定の 課題において高いパフォーマンスを発揮している [Burda 18, Mnih 15, Pathak 17, Singh 05].

しかし, 従来の好奇心に関わるエージェントの研究は, 内発的動機づけと他の基礎的な認知機能との関連を説明 していない. これに対し，認知アーキテクチャの研究で

$\dagger 1$ 本論文は，著者らによる 2 つ国際会議での発表 [Nagashima 20, Nagashima 21] を再構成し, 考察を加えたものである.
は，様々なタスクで共通に利用される基礎的な認知機能の 統合が試みられてきた. 認知アーキテクチャに関わる研究 は古くから行われており, 過去に様々な種類のものが構築 されてきた. しかし，近年，それらのアーキテクチャの差 異は縮小し，共通の構造に集約されつつある [Laird 17]. そして，現存するアーキテクチャのなかで，最も多くの 機能を有し，最も多くの先行研究に利用されているのが, ACT-R (Adaptive Control of Thought-Rational[Anderson 07]) である（[Kotseruba 18] による網羅的なレビューを 参照).

上記の背景から，本研究では認知アーキテクチャの典 型として ACT-R に焦点を当てる. ACT-Rは，個々の認知 機能をモジュール [Fodor 83] という基本的な単位に割り 当てる. ACT-R のモジュールは, 脳部位と対応し, fMRI を用いた脳計測などによってその挙動に関わる検証が進 められている [Anderson 05]. さらに, ACT-R が有する モジュールの中には，強化学習に近い機能を果たすもの 
も含まれ，そのモジュールを，知識を用いた推論に関わ るより高次のモジュールとインタラクションさせること ができる.

本論文では ACT-R に組み込まれた基礎的なモジュー ルを組み合わせ，内発的動機づけのメカニズムを提案す る.そして，その利点として，豊富な ACT-R の先行研 究に従うことで，複数の認知機能（モジュール）との関 係の中で，課題の学習に対する内発的動機づけの影響を 探究できることを主張する。この主張を補強するために， 提案メカニズムを異なる認知機能を有する複数のモデル に組み入れる。そして，そこで生じた振る舞いを検討す ることで，提案する内発的動機づけのメカニズムが，多 様な局面の人間の学習を表現できることを確認する.

以下，本研究の提案メカニズムを示す前に，このテー マに関連する先行研究を示す。その上で，ACT-Rを用い た内発的動機づけのメカニズムを提案し，その有効性を シミュレーションにより検討する．最後に，得られた示 唆をまとめ, 今後の方向性を示す.

\section{2. 関 連 研 究}

本研究は, 内発的動機づけのメカニズムを ACT-Rに よって表現する.この目的と関連した研究として，(1)人 間および人工エージェントによる内発的動機づけに関わ る研究，(2) ACT-R の構造と環境の学習に関する研究を 紹介する.

\section{$2 \cdot 1$ 人間と人エエージェントにおける内発的動機づけ}

内発的動機づけは，教育やエンターテイメントなど， 幅広い分野において，人間の活動を継続させる動因とな る. 様々な研究者が内発的動機づけの体系化を試みてい るが，本研究では Malone の 3 タイプ [Malone 81] を参 照する．彼は，ビデオゲームの遂行において生じる内発 的動機づけを，教育場面に応用することを狙った．ゲー ムには人の内発的動機づけを刺激する工夫が凝らされて いる. Maloneによれば，人がゲームを継続する動機は， 困難な目標の達成によって得られる「チャレンジ」，対 象に対する想像を自由に膨らませることによって得られ る「ファンタジー」，そして意外なことや興味深いこと， 楽しいことによって刺激される「好奇心」を含む.これ らの内発的動機づけのタイプは，相互にオーバーラップ しており，厳密に分けられるものではない。しかし，内 発的動機づけにこれらの側面があることを受け入れ，相 互の関係を考慮することで，モデル化すべき内発的動機 づけの指針を設定できる.

Malone による分類のうち，チャレンジに関わる動機 づけは，内発的動機づけの最適水準に関わる議論 [Csikszentmihalyi 90, Yerkes 08] と関連する。人間には，内発 的動機づけが刺激される適切な課題の難易度がある。そ の課題に対して内発的動機づけが高すぎても低すぎても 効果的ではないとされる.さらに個人にとって適切な難
易度の設定は個人の好む思考水準にも依存する.人間の 思考水準は，高速で働く短絡的思考と，低速で働く熟考 的思考などに区別できるとされる [Brooks 86, Kahneman 11]. これらより，その個人が選好する思考水準に適した 課題を設定することで，学習者の内発的動機づけが高め られると想定される.

上記のチャレンジに関わる議論は, Malone の挙げた内 発的動機づけの別のタイプである好奇心とも無関係では ない. むしろ著者らは, 好奇心こそが適切な難易度の課 題において刺激される内発的動機づけのメカニズムであ ると考えている. この好奇心のメカニズムをめぐって, 近 年，様々な人工エージェントの研究が行われている. そ の重要な原理は, 予測䛊差の理論 [Friston 10] に求められ る. 好奇心のきっかけとなる驚きや興味，楽しさなどの 感情は, 経験から得られる予測と現在の状態の認識の不 一致 (予測誤差) によって引き起こされる. 様々な研究者 が，予測誤差の観点から，好奇心に基づく自律エージェ ントを開発してきた [Schmidhuber 10, Singh 05]. たとえ ば，Singh は好奇心を組み入れた強化学習により，エー ジェントに広く環境を探索させる方法を検討した [Singh 05]. 従来の強化学習 (例えば [Sutton 98]）における報酬 が，外部から直接エージェントに付与されるのに対し， 好奇心によって生成される報酬は，予期せぬ反応を契機 （トリガー）として，エージェントの内部に生じる. 近 年, 好奇心に基づく強化学習は, 深層強化学習の枠組み で注目されている [Burda 18, Mnih 15, Pathak 17]. 特に Burda は，好奇心を組み入れたエージェントが，明示的 な外部報酬（ゴールの達成に伴う報酬）を与えられなく ても，幅広く環境を学習し，高いゲームのパフォーマン スを発揮することを示した。

\section{$2 \cdot 2$ ACT-R のモジュール構造と環境の学習}

前節の先行研究では，好奇心に基づくエージェントが 実装された.しかし，これらの研究は内発的動機づけと他 の基礎的な認知機能との関連を説明していない. 1 章で述 ベたように，この関連を検討するためには，認知アーキテ クチャが必要である．以下では，本研究が用いる ACT-R がどのように個別の認知機能を表現するのか，またそれ らの認知機能が組み合わさることによってどのような学 習が実現するのかを説明する. なお，ここでの ACT-Rの 解説は, 本研究における論点を示すための概略的なもの である．詳細は Anderson の著書 [Anderson 07], ACT-R のマニュアル [Bothell 19]，あるいは他のレビュー [森田 20, Ritter 19, 寺尾 15] を参照されたい.

\section{\$1 ACT-R のモジュール構造}

既に述べたように，ACT-R は認知機能をモジュールと 関連づける. 図 1 に含まれるボックスは, 脳の部位と対応 づけられる ACT-R のコアモジュールである．ここで，宣 言的モジュールは言語化可能な経験や知識（宣言的記憶） をデータとして保持し，イマジナルモジュールは複数の 


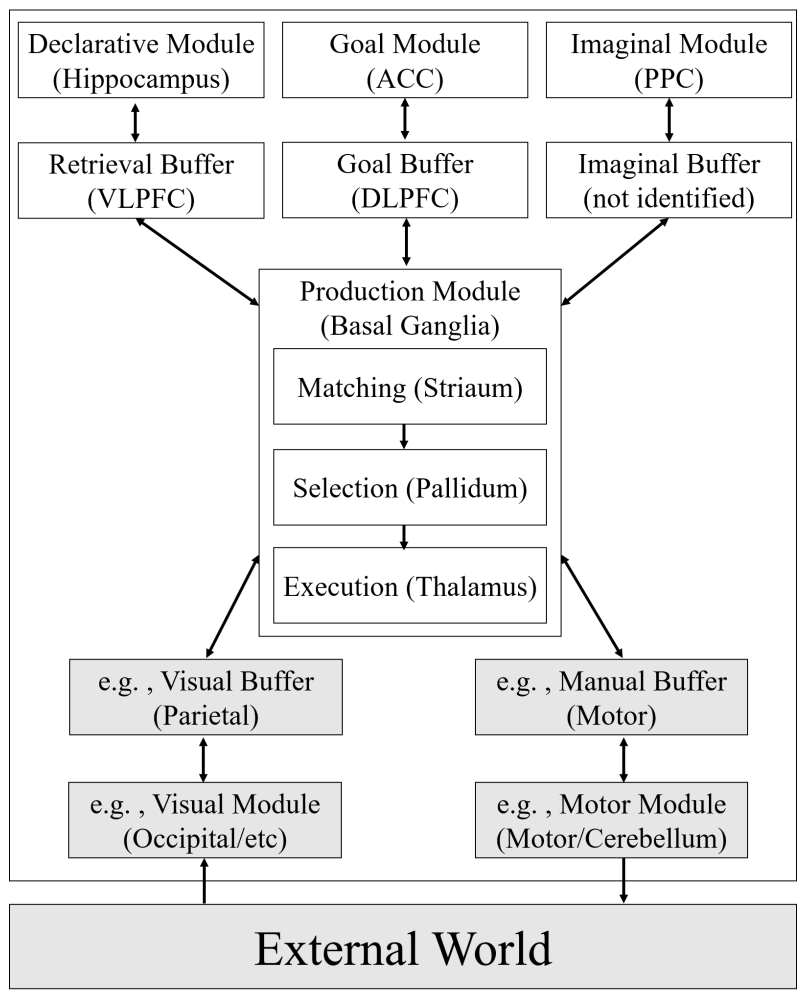

図 1 ACT-Rのモジュールの概要. 本稿で対象としなかったモジュー ルはグレイアウトした. [Anderson 04] を参考に作成した.

宣言的記憶を組み合わせることで新たな宣言的記憶を構 成する．そして，ゴールモジュールは現在モデルが取り 組む課題を制御する情報を管理する。これらのモジュー ルの各時点の状態（想起されている宣言的記憶，現在の 課題の状態など）はチャンクと呼ばれる記号表現に集約 され，バッファに格納される. バッファに格納されたチャ ンクは，プロダクションモジュールに格納されるプロダ クション（IF 節と THEN 節を持ち，人間の手続き的記憶 と対応するルール表現）と照合（マッチング）され，その 結果に基づき，プロダクションが選択される．プロダク ションが実行 (発火) されると, プロダクションモジュー ルから，他のモジュールのバッファへ，モジュールの状 態を操作するコマンド（条件を満たす記憶を探す，課題 の現在の状態を更新するなど）が送信される.

上記のように，ACT-R は複数のモジュールを有し，そ のうちの宣言的モジュールとプロダクションモジュール に異なる記憶が格納される. 宣言的モジュールに格納さ れる宣言的記憶はプロダクションモジュールに格納され る手続き的記憶に比べ，実行のコストが大きい. ACT-R はモデルによる個々の処理に時間的コストを割り当てる. 一回のプロダクションの実行に要する時間的コスト (50 $\mathrm{ms})$ に対し，一回の宣言的記憶の検索に要する時間的コ ストは，他の様々な条件によって影響されるものの，一 般にそれより大きい。

加えて, 宣言的記憶はゴールや外部環境から直接引き 出されない，それを利用する際には常にプロダクション
を介した検索が必要になる，宣言的記憶を検索するプロ ダクションには，個々の宣言的記憶の内容と，現在の各 バッファの状態（認識している外界の状態やゴール）を 柔軟に対応 (パターンマッチング) させるための変数が 含まれる. ACT-R の理論において，パターンマッチング の対象となる宣言的記憶は大脳皮質 (腹側前頭前野) を介 して引き出されるとされる. 対して，それが利用されな い処理は，プロダクションモジュール（大脳基底核と対 応）の比重が大きい. 人間の意識的な処理が前頭前野を 介して行われ，自動的な処理が大脳基底核を介して行わ れると想定すれば [Anderson 07]，ACT-R は，前節で述 ベた人間の異なる思考水準を，パターンマッチングを伴 わない低次の思考とパターンマッチングを伴う高次の思 考に区別するといえる.

\section{§ 2 ACT-Rによる環境の学習}

ACT-R による学習も，パターンマッチングの有無に よって区別できる. パターンマッチングを伴わない学習 は，プロダクションの選択確率を報酬によって変化させる ものであり，従来の強化学習と対応する．たとえば，Fu は，ACT-R を用いて，上下左右の方向に関する知識を保 持し，繰り返し迷路課題を解くモデルを実装した [Fu 06]. Fu のモデルは, Q-Learning [Watkins 89] と似た ACT-R の「ユーティリティ」モジュールを用いる（後述）。そ のモデルは，現在の目標達成につながる行動をしたとき には正の報酬を，目標達成につながらない行動をしたと きには負の報酬を受け取る。このような報酬を得る試行 を繰り返すことで，モデルは迷路探索において最適な行 動をとるように学習した.

他方のパターンマッチングを伴う学習とは，プロダク ション内の変数とマッチングされる宣言的記憶を増やす 学習である. 先の Fu らによる学習と対応する例として, Reitter の研究をあげることができる [Reitter 10]. この研 究では，モデルの宣言的記憶に迷路の位置情報を表現す るトポロジカルマップを構成し，それを利用したバック トラックを用いてパス探索が行われた。ささに，モデル の宣言的記憶に迷路を解決した事例を含めることで，記 憶ベースの環境探索を実現した. ACT-Rにおいて，宣言 的記憶内に過去の問題解決の事例を蓄える学習は，事例 ベース学習 (IBL: instance-based learning [Gonzalez 03]) と呼ばれており，高いパフォーマンスを導く手法として 多くの研究で扱われている.

上記のように ACT-R は，迷路などを題材とした環境探 索の研究で多く扱われている. そのような ACT-Rによる 環境探索に内発的動機づけを組み入れる直接的な研究を 見つけることはできない. ただし，内発的動機づけと関係 する感情的要素のモデルは多く提案されている．たとえ ば Dancy は ACT-R による認知プロセスと生理的なメカ ニズムを結合することで, 感情の生起モデルを構築した [Dancy 15].また，VanVugt は，抑うつを感情を伴う記 憶の割合によって説明する認知モデルを構築した [Vugt 
18]. さらに，Juvina は，そのような感情的記憶と報酬 関数の関係を説明することを目指した [Juvina 18]. これ ら，ACT-R に感情的プロセスを組み入れる研究はいずれ も，ACT-R に新たなモジュールや機能を加えることで， これを達成しようとする．認知機能の統合を理念とする 認知アーキテクチャの思想に従うのであれば，追加され る機能やモジュールは限定されることが望ましい.よっ て，本研究では，報酬関数を直接的に操作するのではな く，そのような関数による報酬の変動が ACT-R による 学習に応じて自然に生じる仕組みを考える。これによっ て，ACT-Rにおいて構築される内発的動機づけのメカニ ズムが，他の基礎的な認知機能とどのような関連性をも つのかを説明できる.

\section{3. 知的好奇心のメカニズムの提案}

本研究で，提案するメカニズムは，内発的動機づけの なかでも知的好奇心に焦点をあてる．ここで报う内発的 動機づけは，[Malone 81] による好奇心の定義（楽しさ による刺激），予測誤差による楽しさの発生原理 [Friston 10, Schmidhuber 10] に加え，高次認知機能（宣言的記 憶）を伴う。この理由により，本研究では好奇心に「知 的」の文字を冠した．以下に，その基本的なアイデアを 示し，その後に関連する ACT-R の既存機能，およびそ の既存機能を活用した知的好奇心のメカニズムを示す.

\section{$3 \cdot 1$ 人間によるパターンの発見と ACT-Rによるパター ンマッチングの対応}

$2 \cdot 1$ 節で述べたように，好奇心は事前の予測と現在の状 況の差分 (予測誤差) によって生じる. 予測誤差から驚き が生じ，そのうちの一部は，楽しさなどの感情的反応を引 き起こし，課題を継続する動因となる．楽しさに関しては 複数の研究者が，環境における新規なパターンの発見と関 連することを指摘している [Caillois 58, Csikszentmihalyi 90, Huizinga 39, Koster 13, Schmidhuber 10]. たとえば, ゲームデザイナーである Koster は，著書の “Theory of Fun for Game Design [Koster 13]”において，人間がゲー ムにおいて感じる楽しさは，ゲーム内での新しいパター ンの発見によって引き起こされると述べる，逆にいえば， 数あるパターンから最適解が発見されたゲームは，遂行 中に「飽き」が生じる，そのため，好奇心を刺激し続け るゲームを開発するためには，ユーザに新規なパターン を発見させ続ける仕組みが必要であるとした。

上記と類似し，かつより形式的な楽しさの理論化は, Schmidhuber による "Formal Theory of Creativity, Fun, and Intrinsic Motivation [Schmidhuber 10]”おいてなされ ている.この理論において，パターンの発見は，データの 中で反復される定型的なパターンを発見し，圧縮するこ とと定義される．ここにおいて，データの圧縮は予測と 同義の意味を持つ. 圧縮されたデータの利用により，将来 的な課題の成績が向上することが仮定されるためである.

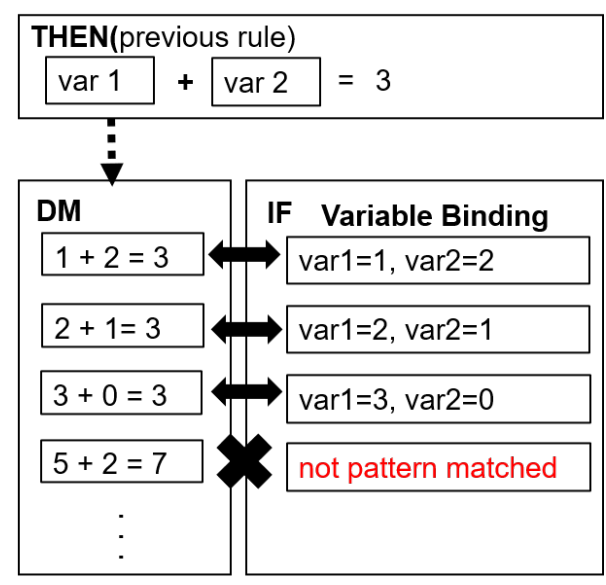

図 2 ACT-R のパターンマッチングの簡単な例. この例では，前の プロダクションの THEN 句で宣言的モジュール（図中では DM と表記）に宣言的記憶を問い合わせ，次のプロダクショ ンの IF 節で変数が束縛される流れを示している.

Schmidhuber は，データを圧縮すること，あるいは圧縮 可能なデータを取得することを楽しさと対応づけ，楽し さを最大化する強化学習エージェントの枠組みを示した.

これらの理論を引き継ぎつつ，環境やデータからパター ンを発見する仕組みとして，本研究はパターンマッチン グに注目する．パターンマッチングそのものは，テキス 卜検索における正規表現など，計算機科学において用い られる汎用的な仕組みである。ACT-Rにおいても，2.2 節で触れたように，高次の認知プロセスを説明する中心 的な仕組みとなっている.

図 2 は，ACT-R のパターンマッチングを説明するため の簡単な例を示している.この例では，ACT-Rのプロダ クションの THEN 句に含まれる変数“var1”と“var2”を， 宣言的記憶の定数である 1 や 2 などの数值に束縛させて いる。このようにパターンマッチングは，プロダクショ ンに埋め込まれた変数のパターンに応じて，データ（宣 言的記憶）と環境（現在のモジュールのバッファの状態） を対応づける構造を発見する。この仕組みは人間の認知 の柔軟性を説明するとされ，類推に代表される関係的推 論，ゴールを状況に応じて変更するメタ認知など，人間 に固有とされる認知機能のベースとなるとされる ${ }^{* 1}$.

なお，Malone は好奇心を感覚に由来するものと高次 認知機能に由来するものに区別し，後者によって「自分 の知識構造をより良い形にしたいという欲求」が生じる とした [Malone 81]. このことから，我々はパターンマッ チングによってデータの構造を発見することは，知識構 造の整理に結びつき，知的好奇心を充足させると考えた. そして，これらを結びつけ，ACT-R のパターンマッチン グが，人間による知的探究（パターンの発見），すなわ ち知的好奇心と対応するのではないかと考えた。

*1 Anderson は「ダイナミック・パターンマッチング」と呼ばれ る ACT-R の機能の導入時にこの主張をした [Anderson 07]. 


\subsection{ACT-R による知的好奇心の減衰メカニズム}

前節において ACT-R のパターンマッチングを知的好 奇心と関連づける基本的なアイディアを述べた．そのよ うな知的好奇心が，一般的な認知プロセスにおいて果た す役割を説明するためには，その減衰（飽き）のプロセ スを検討する必要がある. 飽きは刺激の飽和によって生 じ，学習のプロセスと関わりがある.よって，以下では ACT-R の学習機能である「ユーティリティ」と「プロダ クションコンパイル」について説明する.

\section{$\S 1$ ユーティリティ}

$2 \cdot 2$ 節で触れたように，この機能は強化学習と対応し， ACT-R が有する 2 種類の記憶のうち，プロダクションの 利用のされ方を規定する. 複数のプロダクションが現在 の状況とマッチするとき，プロダクション $i$ が選択され る確率は,

$$
P(i)=\frac{e^{U_{i} / \sqrt{2 s}}}{\sum_{j} e^{U_{j} / \sqrt{2 s}}}
$$

に従う. $e$ は自然対数の底, $s$ はロジスティック分布に従っ てノイズの分散を決定するパラメータである，jは競合 するプロダクションを表し，Uは以下によって制御され るプロダクションのユーティリティを表す.

$$
U_{i}(n)=U_{i}(n-1)+\alpha\left[R_{i}(n)-U_{i}(n-1)\right]
$$

$\alpha$ は学習率を表し， $R_{i}(n)$ は時刻 $n$ においてプロダク ション $i$ が得る報酬である. 報酬が与えられる度に，前 回の更新 $(n-1)$ 以降に発火した全てのプロダクション のユーティリティが，この式によって更新される。この 学習は, Q-learning と呼ばれる強化学習に近い手法とさ れている [Fu 06].

ユーティリティを利用したプロダクションの競合解決 は，ACT-Rによるモデルの実行の様々な場面で生じる. 本研究ではとくに，課題を継続するか，課題を終了する かを決定する仕組みにユーティリティの学習を活用する. そして，この学習における報酬を調整する仕組みとして， 次に説明するプロダクションコンパイルを活用する.

\section{§2 プロダクションコンパイル}

プロダクションコンパイルとは，連続して実行される 2 つのプロダクションを 1 つのプロダクションに圧縮する 機能である [Taatgen 03]. ある課題において，一連のプロ ダクションが反復発火することで，プロダクションの圧 縮が起き, 課題達成までに発火するプロダクションの数 が削減される，圧縮の対象となるプロダクションは，IF 節に変数を含むものである.つまり，プロダクションコ ンパイルは，プロダクションの IF 節とモジュールの状態 （たとえば宣言的モジュールに含まれる宣言的記憶）を対 㐫づけるパターンマッチングのプロセスを圧縮する。 こ れにより，圧縮前のプロダクションに含まれていた変数 は，個別の宣言的記憶の值に置換される．そのため，定 型的かつ自動的に課題を遂行するプロダクション（手続 き的記憶）が生成され，課題への慣れが生じる. 先述し

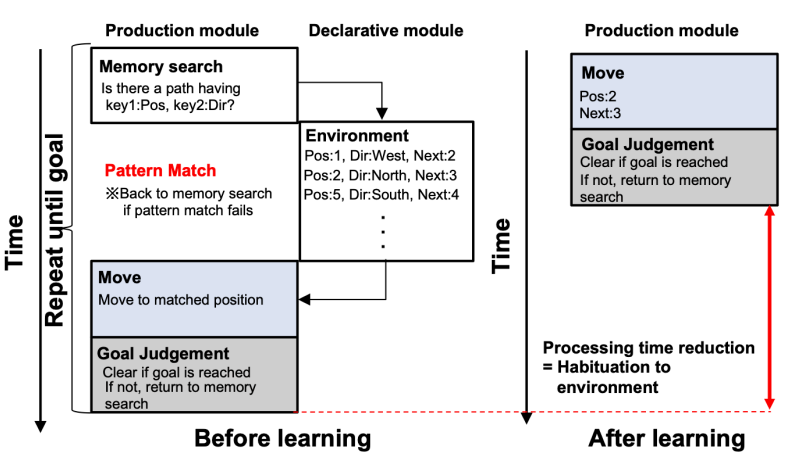

図 3 プロダクションコンパイルモジュールによる学習前と後の例

た楽しさの理論 [Schmidhuber 10] に基づけば，パターン マッチング（データ中の構造の発見）によって生じてい た楽しさが，プロダクションコンパイルよる圧縮によっ て減衰するといえる.

図 3 は後述のシミュレーションで使用する迷路課題に おける ACT-R モデルのトレースを示す，縦軸に時間を示 し, 各列はモジュールのイベントを示している. 左側の トレースは，宣言的記憶を用いてパス探索を行うモデル の処理を表している. 右側のトレースはプロダクション コンパイルによる学習後，宣言的記憶を取得せずにパス 探索を行うモデルの処理を表している.

\section{$3 \cdot 3$ 課題継続のメカニズム}

ここまでに示した ACT-R の基本機能を用いて，課題 の継続と終了を判断するメカニズムを提案する. 図 4 は, 一般的な環境における課題継続のメカニズムを示す．各 ラウンド（課題の繰り返しに関する単位）の開始時に，モ デルは課題継続プロダクションと課題終了プロダクショ ンを競合解決させる ${ }^{* 2}$. 課題継続プロダクションが発火 した後，モデルは課題を遂行するためのプロダクション 群（マップの探索など）を発火させてラウンドを進める. ラウンドを終了する条件に遭遇すると，新たなラウンド を開始し，再び課題継続プロダクションと課題終了プロ ダクションを競合解決する.

本研究では, 上記のフローにおいて, 課題継続プロダ クションは, 課題終了プロダクションに比べ，高い初期 のユーティリティをもつと考える. 課題開始時に，人間 は，ある程度課題継続の意思があると考えるためである。 この初期状態からの「飽き」のプロセスは，各ラウンド の終了を認識するプロダクションの発火を負の報酬のト リガーとすることで生じる．ラウンド終了時に負の報酬 が与えられると，そのラウンドにおいて競合解決の結果 として発火したプロダクション（すなわち課題継続プロ ダクション）のユーティリティが低下し, 課題終了プロ ダクションが選択される確率が増加する.

*2これらも通常のプロダクションと同様にプロダクションモ ジュールに格納される. ラウンドの開始を示すチャンクがゴー ルモジュールのバッファに格納された際に 2 つのプロダクショ ンの競合解決が生じる. 


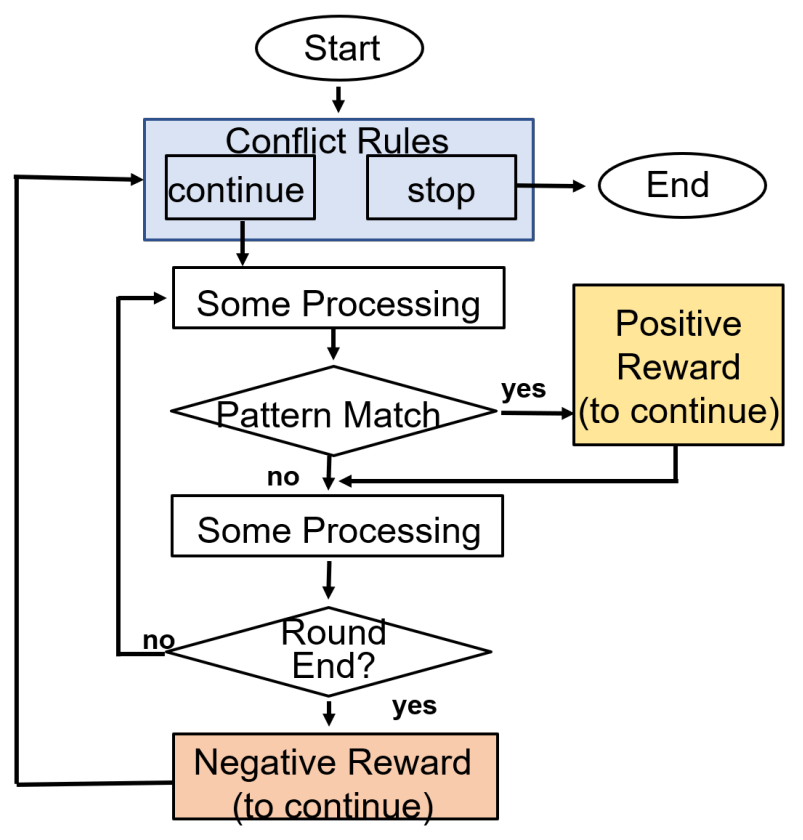

図 4 課題継続モデルのフローチャート. パターンマッチングが発 生すると正の報酬が得られる。

「飽き」を抑止し，課題を継続させるには，課題中に 「楽しさ」と対応するプロセス（正の報酬のトリガー）を 生起させる必要がある。本提案においては,「楽しさ」を 感じるプロセスを，宣言的記憶の検索成功（地図を思い 出せた，他者の振る舞いを予測できたなど）と定義する. 宣言的記憶の検索にはプロダクションの IF 節（現在の状 況）と宣言的モジュール内の宣言的記憶とのパターンマッ チングが伴われる。これに成功することは，先述した楽 しさの定義 [Koster 13, Schmidhuber 10] と合致する．た だし，同一のプロダクションの適用が繰り返されると慣 れ，つまりプロダクションの圧縮が起こる。「楽しさ」を 伴うプロセスが圧縮されることで，ラウンドの終了を認 識するプロダクションに付与された負の報酬が，課題継 続プロダクションのユーティリティを減ずるようになる. つまり，このメカニズムにおける課題継続の要因は，パ ターンマッチングの対象となる宣言的記憶（データ）の 発見により，知的好奇心を刺激し続けることである.

\section{4. シミュレーション}

前章で提案した知的好奇心のメカニズムを具体的な課 題に実装し，動作を確認するシミュレーションを行った。 以下，シミュレーションの目的を明らかにした後に，具 体的な課題，モデルの詳細と設定を述べる．最後にその 結果を示す。

\section{$4 \cdot 1$ 目的と指標}

提案するメカニズムの性質を検討するために，以下の 連続する 2 つ問いを検討する。

(1) 提案する知的好奇心はどのような環境において刺 激されるのか
（2）刺激された知的好奇心は，課題の学習にどのよう に作用するのか

1つ目の問いに答えるために，モデルを取り巻く環境 を，外部と内部に区別して操作する．外部環境は学習環 境の複雑さ（難易度），内部環境はモデルが使用できる 環境探索の戦略に対応づける。そして，これらの環境要 因が知的好奇心に与える影響について，

(a) 課題の継続回数（図 4 の課題継続プロダクション (continue) の発火回数)

を指標として検討する．統制された条件のもとでの課題 の継続は，知的好奇心が刺激される環境を探る指標とし て有用と考えた。さらに，刺激された知的好奇心が，課 題の学習に対して与える影響を,

(b) ゴール達成率

(c) 環境探索の行動の複雑さ

(d) 新たに生成されたプロダクションの数

を指標として検討する. (b) は課題の学習パフォーマンス に関する直接的な指標であり，(d) は課題継続によるモデ ル内部の変化を表す。そして，(c) はパフォーマンスと内 部変化を結ぶ行動に関わる指標である．モデルの行動の 複雑性として，本研究では，環境中でモデルがとりうる 状態の生起頻度を正規化し，

$$
H r=\frac{-\sum_{i \in n} p\left(x_{i}\right) \log p\left(x_{i}\right)}{\log n}
$$

のようにエントロピーとして計算する． $x_{i}$ は環境中の特 定の状態， $n$ はある環境に含まれる状態の総数である. この指標は，モデルが広範囲に環境を探索すると増加し， 局所的な探索を行うと減少する.

\section{$4 \cdot 2$ 課題：外部環境の操作}

$2 \cdot 2$ 節に示した ACT-R の先行研究を引き継ぎ，迷路探 索を課題とする. 本研究では，一定のサイズのグリッド に対して，迷路生成アルゴリズム $* 3$ を適用し，ループ構 造を含まない複数のマップを自動生成した。このアルゴ リズムに付与するパラメータとしてグリッドの大きさを $5 \times 5,7 \times 7,9 \times 9$ に変化させた. それぞれの大きさに 対して，10 の異なるマップを用意した. 図 5 にマップの 例を示す．探索対象となる迷路のサイズを変化させるこ とで，課題の難易度が変化する．2.1 節にて述べたよう に，適度な難易度の設定は，内発的動機づけを刺激する と想定できる．よって，これら異なる外部環境を比較す ることで，提案する知的好奇心が刺激される要因を検討 できる。

これらの外部環境をモデルに与える方法として，実装 上で簡易なものを採用した. ACT-R は視覚や運動など外 部環境と相互作用するモジュールをもつ．それらを利用 することで，3 次元的な迷路を探索させる研究も存在する [Turner 16]. しかし，そのような完全なモデルはシミュ

*3 https://algoful.com/Archive/Algorithm/MazeExtend 


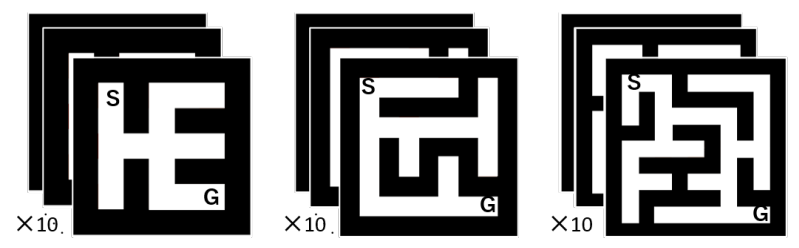

図 5 外部環境の操作

レーションの実行コストが大きい. 本研究では, 多数回の 実行による安定した結果を得るために, 知覚や運動のプ ロセスを排除し，マップの構造に関する記憶を直接モデ ルの宣言的モジュールに含めた ${ }^{* 4}$. モデルに与えるマッ プは，迷路の曲角の繋がりをノードとするトポロジカル マップであり，ノードおよびノード間の結合（パス）が チャンクとして表現される. 課題の実行においてモデル は，宣言的モジュールに格納されたパスの記憶（連結さ れる2つの曲角とその方向）を，プロダクションルール に埋め込まれた変数のパターンとマッチングすることで 発見する.

上記のように構築されたトポロジカルマップに対して, 迷路の最も左上の曲角を示すチャンクを初期位置と設定 し，スタート位置から最も遠い曲角をゴール位置のチャ ンクとして設定した。 つまり，スタート位置から経由す るホップ数が最も多い曲角がゴール位置として設定され た. なお，複数のゴール位置の候補があった場合は，候補 の中から最も早くホップ数を計算したものが決定される.

モデルは現在自分が位置する曲角を示すチャンクをゴー ルモジュールに格納する，モデルは，スタートからゴー ルに向けて，ゴールモジュール内の現在位置を遷移させ ることで環境を探索する，現在位置の遷移は，宣言的モ ジュールに格納されたパスに関するチャンクを検索する ことで行われる. 現在位置を含むチャンクが呼び出され， そのチャンクと結びつく位置が新たにゴールモジュール に格納される。これをゴールに達するまで繰り返す。つ まり，本研究の課題は，環境に関する宣言的記憶を与え られたモデルが，実際に身体を動かすことなしに，パス プランニング [Reitter 10] を遂行する状況に相当する.

この単純な迷路課題の中で, 前章で示した楽しさや飽 きのプロセスがどのように生じるのかを検討した. スター 卜位置からゴール位置まで移動するか, 制限時間に達す るまでのプロセスを 1 回のラウンドとし，同一のマップ に対するラウンドを繰り返す。この課題において, パター ンマッチングに付随する「楽しさ」は，現在の状況と合 致するパスを宣言的モジュールから検索することと定め る.このような「楽しさ」が生起しないままラウンドを 終了した場合, 課題継続の動機づけが減少すると設定す る.つまり，ゴールに到達したか否かによらず，ラウン

\footnotetext{
*4 基礎的なシミュレーションにおいて知覚と運動のプロセスを 排除することは. ACT-R の公式のチュートリアルにおいても 推奨されている.
}

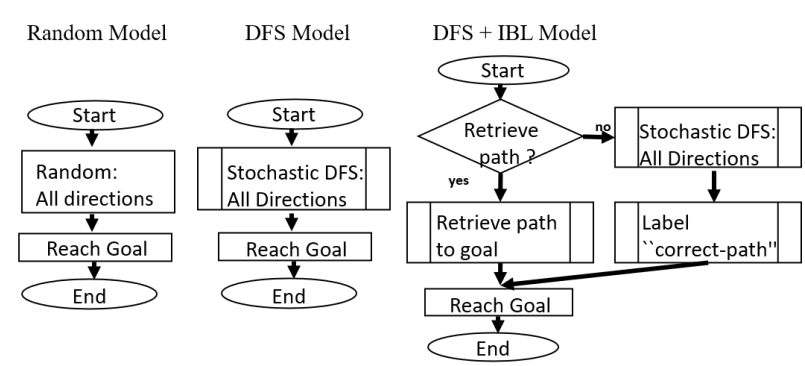

図 6 内部環境の操作

ドの終了時に発火するプロダクションを負の報酬のトリ ガーとする．これにより，パターンマッチングが生じな いままラウンドが終了すると, 課題継続プロダクション のユーティリティは，式 (2)により減少していく，そし て, 課題継続プロダクションのユーティリティが, 課題 終了プロダクションのユーティリティを下回ったときに, 課題終了プロダクションが発火し, 課題が終了する.

\section{$4 \cdot 3$ 探索方略 : 内部環境の操作}

知的好奇心の刺激される内部環境を検討するために, モデルが有する環境探索の戦略を，2·1 節にて述べた思 考水準 [Brooks 86, Kahneman 11] の観点から操作する. $2 \cdot 1$ 節で述べたように，モデルの有する思考水準は，内発 的動機づけの最適水準 [Yerkes 08, Csikszentmihalyi 90] に影響すると考えられる. 図 6 に本研究で構築した思考 水準の概略（1 ラウンドの処理）を示す. 3 つの ACT-R モデルが示され，左から順に課題を遂行する中で利用さ れる宣言的記憶が増大する. 2.2 節 11 に述べたように, ACT-R における宣言的記憶の検索は，前頭前野の活動を 増大させると仮定できる. したがって, 図 6 の左から右に 向かうに従って，深い思考水準を組み入れたモデルと仮 定できる.さらに，本研究では，ACT-R モデルの振る舞 いを明確化するため, Q-Learningによる強化学習モデル を実装した。それぞれのモデルの詳細を以下に記述する。

\section{§1 ランダムモデル}

最も思考水準の低いモデルは，ランダムにゴールモジ ュールの現在位置を遷移させる．ラウンド内において，モ デルはゴールに達するか制限時間に達するまで下記の処 理を繰り返す。

（1）方向の決定：4つの移動方向（東，西，南，北）を 表すプロダクションを式 (1) に基づいて, 確率的に 発火させる. なお，4つのプロダクションのユーティ リティの初期值は等しく設定する.

（2）行き先の決定: 決定された方向への移動が可能か否 かをパスに関わる宣言的記憶を検索することで判断 する.この判断に利用するプロダクションには, ゴー ルモジュールに格納される現在位置と (1) にて決定 された方向が, 変数として含まれる. パターンマッチ ングの結果，該当するパスの記憶が見つからなかっ た場合，(1) に戻る， パターンマッチングに成功する 
パスが見つかった場合，ゴールモジュールの状態を 検索されたパスに従って変更した後に (1)に戻る。一 旦検索されたパスはプロダクションコンパイルされ る.なお，プロダクションコンパイル後のプロダク ションのユーティリティは，プロダクションコンパ イル前のプロダクションのユーティリティよりも低 く設定される．同じ宣言的記憶がプロダクションコ ンパイルされるごとにユーティリティが増大し，最 終的にプロダクションコンパイルされる前のプロダ クションのユーティリティと等しくなる.この設定 は ACT-R のデフォルトの設定に従うものである.

\section{$\$ 2$ 確率的 DFS モデル}

より高次な認知機能（宣言的記憶）をモデルに含める ために，確率的な DFS (depth-first search)，あるいはバッ クトラックによって環境を探索するモデルを構築した。 そ の実装は，先行研究 [Reitter 10] を参考にした. このモデ ルは，図７に示すように，ACT-R のイマジナルモジュー ルで生成されたチャンクを用いたスタック構造を備える. スタック内のプッシュ機能は, ARG1 スロットに過去の チャンク名を格納することで，スタック内のポップ機能 は，ARG1 スロットの值を過去のスロットの值に戻すこ とで実現している.これらの生成されたチャンクは宣言 的モジュールに格納され，後から検索することでポップ機 能が実現される. ACT-R は Lisp で記述されているため, Lisp の処理系にアクセスすることが容易である．しかし， これらの処理はすべて，Lisp など他のプログラミング言 語で書かれた外部関数を定義することなく，ACT-Rのプ ロダクションのみで実装した。

具体的なモデルの動作は，以下の通りである.

(1) 方向の決定: ランダムモデルと同様に，まず移動 方向をランダムに決定する

（2）行き先の決定：ランダムモデルと同様に，現在位 置と移動方向を結ぶパス検索に成功した場合，ゴー ルモジュールの現在位置を変更する。加えて，DFS モデルは，検索されたパスに検索済みのタグを付与 した新たなチャンクをイマジナルモジュールを介し て作成し，宣言的モジュールに格納する。モデルが パスの検索に失敗したとき（行き止まりになったと き)，モデルは検索済みのタグが付与されたチャンク を辿ることで以前の場所に戻り，(1) を繰り返す，ラ ンダムモデルと同様に，確率的 DFS モデルは，パス に関する宣言的記憶をプロダクションコンパイルし， 変数を含まない新しいプロダクションを学習する。

モデルはゴールに到達するか制限時間に達するまで (1) と (2) を繰り返す。パスの検索に失敗した場合，ランダム モデルが直ちにパスの検索を繰り返すのに対し，DFS モ デルは宣言的記憶を検索しながらスタックをポップして いく．そのため，このモデルが効果的に環境を探索する ためには，より多くのラウンドを繰り返し，パスの記憶 を圧縮（プロダクションコンパイル）する必要が生じる.

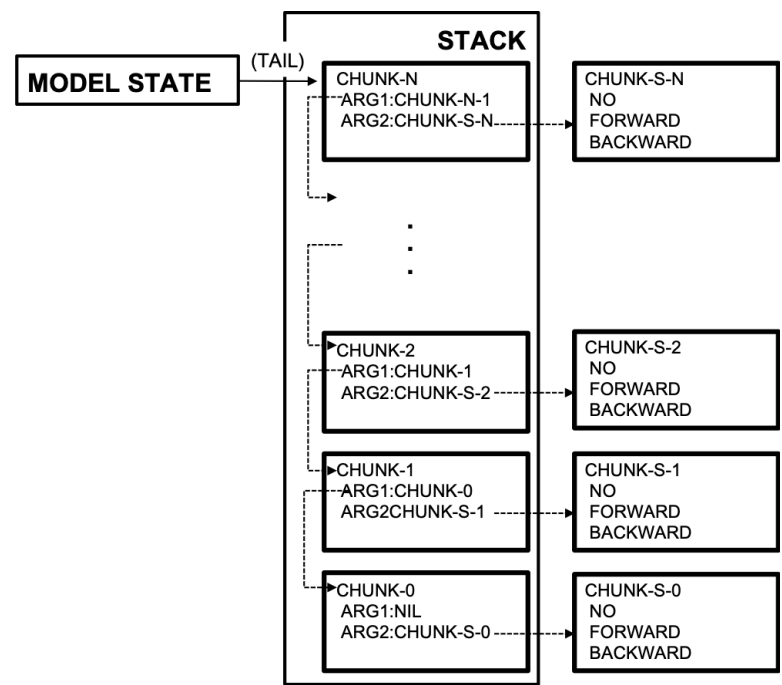

図 7 ACT-R のチャンクで構築したスタック構造.スタックの実装 のために ACT-R のイマジナルモジュールを使用している.

\section{\$3 確率的 DFS と IBL 組み合わせモデル}

このモデルは確率的 DFS と IBL (instance-based learning)を組み合わせる. IBL とは，現在の課題の解決に過 去の記憶を用いる学習方法である [Gonzalez 03, Lebiere 07]. この課題では，各ラウンドの開始から，ゴールに到 達するまで，経由したパスをスタックに蓄える。ゴール に到達した後に，スタック内のパスを辿り，正解ラベルの 付与されたチャンクを生成する. ラウンドの進行は，以 下の 2 つのテップをゴールに到達するか制限時間に達 するまで繰り返す。

（1）方略の決定: DFS 戦略を取るか IBL 戦略を取るか を競合解決により決定する。

（2）方向と移動先の決定

a DFS 戦略を採用した場合は，DFS モデルと同 様に振る舞う。

b IBL 戦略を採用した場合は正解ラベル付きの パスの検索を試みる．失敗した場合は (1) に戻 る. 成功した場合は，正解ラベルの付与された パスに従って現在位置を更新する.

課題の初期段階で，このモデルは確率的 DFS モデルと 同様に振る舞う。ラウンドが繰り返され，正解ラベル付 きのパスの記憶が増加すると, 効果的にゴールに到達で きるようになる，IBL は，DFS に比べて，時間を要する コストの大きい処理である. 正解ラベルをパスに付与す るためには，ラウンドの終了時にスタック内のパスを検 索しなければならない。 また，パスの選択時にて，過去 のラウンドの記憶を思い出すことも，他のモデルには存 在しない時間的コストとなる.

\section{§4 Q-Learning における内発的動機づけ}

ACT-R において構築されたモデルの比較条件として， ACT-R を利用しない Q-Learning による内発的動機づけ のモデルを構築した. なお，本研究の ACT-R モデルが知 
覚や運動に関わるプロセスを含まないことから，ニュー ラルネットワークを用いる深層強化学習を対比条件とし なかった. $2 \cdot 1$ 節に示した従来手法の中でも，最も基本的 なフレームワークと対比させることで, 本研究で提案す るアプローチの特徵を把握することを試みた。

構築した Q-Learning モデルは, 現在位置から移動する 方向（東，西，南，北）を選択する.この選択の際のモ

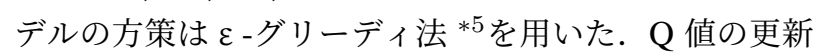
は，強化学習モデルにおける内発的動機づけの先行研究 [Singh 05] 参考に,

$$
\begin{aligned}
Q(s, a) \leftarrow & Q(s, a) \\
& +\alpha\left[r_{i}^{\prime}+r_{e}^{\prime}+\gamma \max Q\left(\dot{s}^{\prime}, \dot{a}\right)-Q(s, a)\right]
\end{aligned}
$$

によって決定した. $r_{e}$ は外部環境からの報酬， $r_{i}$ は内 部環境からの報酬である。モデルは，現在地から移動で きない方向を選択した場合 $r_{e}=-1$ を受け取り, 移動で きる方向を選択した場合 $r_{e}=0$ を受け取る.また，モデ ルがゴールに到達すると $r_{e}=10$ を受け取る。 $r_{i}$ は,

$$
r_{i}=-\tau(1-p) \log (1-p)
$$

として決定される。 $p$ は $\mathrm{Q}$ 值を用いて計算された遷移確 率である. この式から，内部報酬 $r_{i}$ は， $p$ に対する余事 象の確率のエントロピーとして決定される.また， $\tau$ は， 知的好奇心の大きさに相当し, 内部報酬の計算で用いる 係数である.

\section{4 設定}

ACT-R モデルにおいて，課題継続プロダクションの 初期のユーティリティを 10, 課題終了プロダクションの 初期のユーティリティを 5 とした ${ }^{* 6}$. また, ラウンドの 終了を判定するプロダクションには負の報酬のトリガー $(r=0)$ を，パスの発見によって発火するプロダクション には，知的好奇心との対応から，正の報酬のトリガーを 割り当てた ${ }^{* 7}$. そして，その正の報酬を 1 から 20 まで 変化させることでモデルが有する知的好奇心の強度を操 作した. シミュレーションは，知的好奇心と対応する報 酬の各設定值に対して 1,000 回実行された。これを外部

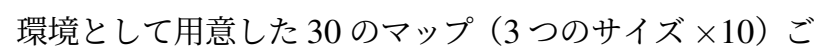
とに繰り返した. なお，各ラウンドの制限時間を ACT-R によって規定されるシミュレーション時間の 100 秒に設

\footnotetext{
$* 5$ epsilon $=0.2$, gamma $=0.9$, alpha $=0.2$

*6 探索方向 (上下左右) を確率的に決める各プロダクションの ユーティリティの初期值をそれぞれの 10 とした。 また，[Anderson 04] に従い，記憶の想起のノイズである ans (activation noise level) $=0.4$, 課題継続プロダクションと課題終了プロダ クションのユーティリティの比較のノイズである egs (expected gain $\mathrm{s})=0.5$ と設定した.

*7 本研究は, パターンマッチングを知的好奇心の源泉と捉える. そして，パターンマッチングは，DFS や IBL におけるスタッ クの操作においても生じる. ただし，本研究ではスタックの操 作におけるプロダクションを正の報酬のトリガーとせず，3つ のモデルに共通のプロセスにおいてのみ知的好奇心と対応する 報酬を割り当てることにした.
}

定し，一回の実行におけるラウンドの最大数を 80 に制 限した.ラウンドの制限時間に達するとモデルはゴール の達成によらず次のラウンドに移行した.

Q-Learning モデルにおいても，30 のマップに対してシ ミュレーションを実施する点, 一回のモデルの実行におけ るラウンドの最大数を 80 ラウンドに制限する点, 内部報 酬を 20 段階に分割する点は同じである。ただし，ACT-R と 4.3 節 $\S 4$ のモデルでは，内部報酬のスケールが異なる ため, 対応づけは容易ではない. 本研究では試験的に, 式 (5)における $\tau$ の值を 0.34 から 0.74 まで 20 段階に変化 させた. このとき内部報酬 $\left(r_{i}\right)$ の合計とノイズ (egs)を 足したものを閾值 $(t h=5)$ と比較することで，タスクを 終了するか，継続するかを選択した．また，ACT-Rにお いてシミュレーション時間として設定した 1 ラウンドに おけるモデルの行動の限界については, 100 ステップとし た. ステップ数が限界に達するとモデルはゴールの達成に よらず次のラウンドに移行した，さらに，Q-Learningに おけるモデルは，ACT-Rに比べてょり高速に実行できる ため，各報酬の設定值に対するモデルの実行数は 10,000 回とした.

\section{$4 \cdot 5$ 結果}

図 8 は，4·1 節に示した各指標に対して，内部報酬の関 数としての結果をまとめている. グラフ中の各ポイントは 内部環境と外部環境 (マップの大きさ) の条件ごとに集計 した平均值（ACT-R モデルは $n=10,000$, Q-Learning モデルは $n=100,000 ）$ を示している. 外部環境である マップの影響は各グラフ中の 3 つの系列の比較によって 検討できる.これらの系列は各サイズに含まれる 10 の マップの平均を示す.モデルの内部環境の影響に関して は，並べられたグラフを横方向に比較することで検討で きる. 以下では，本シミュレーションの目的として提示

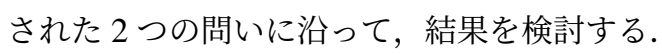

\section{$\S 1$ 知的好奇心を刺激する環境}

図 8 の (a)の課題の継続数は, 知的好奇心がどのように 刺激されているかを表している。この指標は，内部環境が 強く影響していることがわかる. 左2つのモデル（DFS＋ IBL，DFS）と Q-Learning では，内部報酬が大きいほど 課題の継続回数が増加した。 それに対して，ランダムモ デルでは，逆U 字型のグラフとなった．報酬の值が 14 前後までは課題の継続数が増加し, それ以上は課題の継 続数が減少した. この逆 U 字型効果は, 内発的動機づけ に関する理論で頻繁に指摘される最適水準の存在を示唆 している．たとえば，Yerkesによる古典的理論 [Yerkes 08] は，学習者の覚醒度が上がると，ある時点まではパ フォーマンスが向上し，その時点を超えるとパフォーマ ンスが低下することを主張している.

外部環境の効果のあらわれ方（3つの系列の差異）に関 しても，4つのモデル間で異なる. 左 2 つモデルでは, 課題の継続への外部環境の効果に共通の傾向を観察でき 


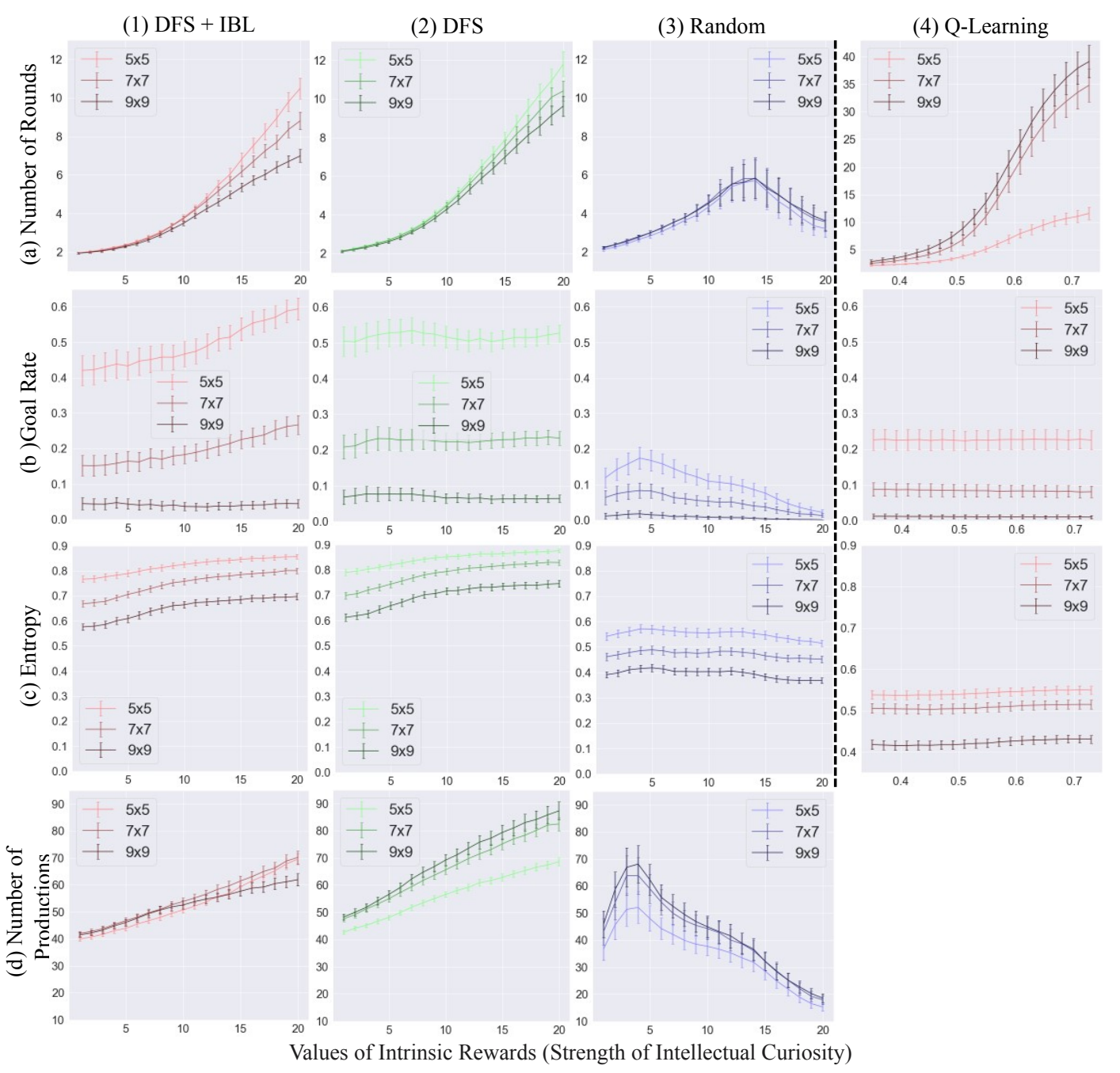

図 8 シミュレーション結果. 横方向に並ぶ数字によってモデルを区別し（1-3: ACT-R モデル，4: Q-Learning モデル)，縦方向のアルファベットにより指標を区別する (a: ラウンド継続数, b: ゴール達成率, c: エン トロピー). ACT-R モデルのみプロダクションコンパイルによって生成されたプロダクション数 (d) を示 す.それぞれのグラフのエラーバーは各マップにおいて得られた標準偏差 (ACT-R: $n=1,000$, Q-Learning: $n=10,000)$ の平均 $(n=10)$ に $1 / 10$ を乗じた值を示す $* 8$. 横軸は，知的好奇心の強度に基づく報酬を表す.

る.これらのモデルでは狭いマップにおいて課題が継続 し，広いマップでは課題が継続しなかった.つまり，DFS を広い環境に適用することは，内部報酬の獲得において 有効ではないことを示唆している. DFS 戦略では，パス を見つけるためにバックトラックが必要である. バック トラックの時間的コストはマップが大きくなるにつれて 増加し，限られた制限時間内にパスを発見する機会を減 少させたと解釈できる．対照的に，ランダムモデルでは 外部環境による課題継続の差が見られず，Q-Learning で は，広いマップほど課題が継続した。このことから，思 考の時間コストを見積もらない Q-Learning では，広い マップに存在する豊富なパターンが発見されることが示 される。

*8 n の大きさに依存する標準誤差ではなく標準偏差に基づく值 を示すことで，データのばらつきの程度を示している.

\section{§2 課題継続が学習に与える影響}

図 8 の残りの指標 $(\mathrm{b}, \mathrm{c}, \mathrm{d})$ は，知的好奇心によって刺 激された課題継続がタスクの学習にどのように影響する かを示している. 左 2 つモデル（DFS＋ IBL，DFS） においては，内部報酬が大きい条件ではエントロピーと プロダクション数が増加している.この結果から，これ らのモデルにおいて刺激された知的好奇心は，環境探索 を広げる効果をもつことがわかる，さらに，ゴール達成 率の結果においては，IBL の効果を見ることができる. IBL を用いるモデル（図 8-1-b）は，特に小さいマップに おいて内部報酬がゴール達成率に正の影響を示している. 一方で，IBLを有さないモデル（図 8-2-b）において，内 部報酬の増加は，ゴール達成率に寄与しなかった.

なお，IBL そのものは，必ずしもゴール達成率に対し て有効に働くわけではない. 内部報酬が少ないグラフ左 側の条件において，IBLを有するモデル（図 8-1-b）は IBL を有さないモデル（図 8-2-b）に比べてゴール達成 
率が低い，IBL がゴール達成率に寄与する条件は，大き な内部報酬が与えられるグラフ右側に限られた。前述し たように，IBL は学習コストを要する戦略であり，経験 を活かして性能を向上させるには，より長期の課題継続 が必要になる。一方，IBL を有さないモデルのゴール達 成率（図 8-2-b）が示すように，ゴールに関連する事例を 宣言的記憶に記録できないモデルは，ゴールへの指向性 が生じないため，知的好奇心の増大はタスクの学習に結 びつかない.

思考水準の低いランダムモデルは，上記 2 つのモデル とは全体的に異なる傾向を示した. ラウンド継続数の結 果と同様に，ゴール達成率（図 8-3-b)，プロダクション 生成数（図 8-3-d）にも逆 U 字型の傾向が見られる.こ れら 2 つの指標の逆 $\mathrm{U}$ 字型のピークは，ラウンド継続数 よりも低い内部報酬の条件で生じる.ささら，エントロ ピーに関しては，内部報酬の増大が僅かながら負の効果 を持つようにも見える（図 8-3-c）。これらの結果から， 思考水準の低いモデルにおいて，内部報酬の増大は，目 標達成に効果的な高次のプロダクションを構築するので はなく，低次の行動（探索を拡大せずに同じ場所を繰り 返し訪れる）を強化し，そのエリア内の環境中のパター ンを取り尽くしていることが示唆される。

比較条件として設けた Q-Learning モデルでは，報酬が 高くなるほどラウンド継続数が増加するが，ゴール達成 率（図 8-4-b），エントロピー（図 8-4-c）に変化が見ら れなかった。一般的に，課題中に特別なイベントがない 環境では（正の報酬はゴール時のみ），Q-Learning はう まく動作しない，そのため，モデルはこれらの環境を学 習できていないと考えられる.

\section{5. おわりに}

本研究は, 認知アーキテクチャの典型として ACT-R を 用い，その中での内発的動機づけのメカニズムを提案し た. 本章では，本研究において構築されたメカニズムの 意義を述べ，今後の展望を示す.

\section{$5 \cdot 1$ まとめと本研究の意義}

本研究で提案したメカニズムは，パターンマッチング が知的好奇心の源泉である「楽しさ」を表し，ACT-Rに 組み入れられた学習のメカニズムにより，その減衰が表 現されると仮定する．この提案を補強するために，異な る思考水準に対応する複数のモデルを実装し，それぞれ のモデルにおける知的好奇心の役割をシミュレーション によって検討した．その結果，パターンマッチングに付 与される報酬は，異なる思考水準のモデルに対して異な る効果を与えた。最も低次なモデル（ランダムモデル） において，高い知的好奇心は負の効果を与え，ゴールの 状態を記憶しないモデル（DFS モデル）においても，課 題のパフォーマンスには結びつかなかった．知的好奇心 の恩恵を受けたモデルは，ゴールにつながった過去の経
験を記憶し，それを現在の状況に生かすことのできるモ デル（IBL + DFS）のみであった.

この結果は, 人間の内発的動機づけに関わる研究とも 整合的である. Malone が述べたように内発的動機づけは チャレンジによって駆動される [Malone 81]. しかし，過 度に難しい課題に対するチャレンジは，図 8 において広 いマップの学習が進まなかったように，有効ではない結 果となる可能性がある。人間に関する内発的動機づけは, 短絡的な思考水準において負の効果をもつとも言われて いる. たとえば，[Pink 11] は，内発的動機づけを刺激す るためには, “autonomy”, "mastery”, "purpose”といっ た熟考するプロセスが必要であると述べた。また，内発 的動機づけの負の効果に関しては，様々な行動嗜癖とし て報告されている [Alter 17]．たとえば，インターネット などの探索作業中，人はしばしば目標を忘れてパフォー マンスを低下させる．このような不合理な行動を導く行 動嗜癖（インターネット中毒）のモデル化は, 「計算精神 医学」のテーマにも繋がる可能性がある [Huys 16].

本研究の意義は，上記のように人間の内発的動機づけ と対応づけられるシミュレーションモデルを構築したこ とである。このような対応は，認知アーキテクチャであ る ACT-R を利用することで得ることができた．ACT-R は神経科学的な背景のあるモジュールをもち，それが心 理学において議論されてきた基礎的な認知機能（宣言的 記憶や手続き的記憶）と対応づけられる。こういった対 応を利用することで，上記のように人間の内発的動機づ けに関わる議論を展開できる.

また，本研究では，ACT-Rによるモデルだけでなく，伝 統的な Q-Learning による内発的動機づけのモデル [Singh 05] を構築した. 結果として，この伝統的なモデルのみ では，課題の学習に有効な行動が獲得されなかった。た だし，本研究は，Q-Learning に対する ACT-R の優位性 を議論するものではない，本研究における Q-learning の 行動は，式 (4)の $r_{i}$ と $r_{e}$ のバランス調整や，好奇心を 刺激する迷路環境の注意深い設計 [Burda 18] により変化 する可能性がある．また，ACT-R と同様，高次の知識処 理（環境モデルの学習）を付与していくことで，内部報 酬が学習に寄与する状況を構築できる可能性がある．特 にオプションによる階層型のスキル学習 [Singh 05] は, ACT-R のプロダクションコンパイルと類似した特徵を持 つと考えられる.よって ACT-R と Q-Learnig の差異は本 質的なものではなく，Q-Learning への機能の付与によっ て解決できると考える。逆にいえば ACT-R はそのよう な機能をアーキテクチャに組み込まれたモジュールとし て，あるいは先行研究におけるモデルから流用すること で，容易かつ曖昧性なく利用できるメリットがある．本 研究は，このメリットを活かし，宣言的記憶と手続き的 記憶という基礎的な認知機能の相互作用からの知的好奇 心の説明を可能にしたと考えている。 


\section{$5 \cdot 2$ 今 後 課 題}

本研究は ACT-R を用いた新たな知的好奇心のメカニ ズムを提案するものであり，今後検討すべき多くの課題 を提示している．以下では，本研究の発展として，(1) 知 的好奇心のメカニズムに関するより深い理解，(2) 知的好 奇心のメカニズムによる知識発見，(3) 環境とのインタラ クションを含めたモデル構築の方向を示す.

\section{$\$ 1$ 知的好奇心のメカニズムに関する深い理解}

本研究の直接の発展は，シミュレーションで得られた 結果の詳細な分析である．熟考的なモデルの結果におい て，内発的動機づけの高まりに伴い，課題の繰り返し回 数が上昇し，パフォーマンスが向上することが示された. しかし，パフォーマンスの向上に伴うパラメータ間の詳 しい関係は分析できていない.内発的動機づけが学習に 及ぼす効果をさらに検討する際に，これらのパラメータ 間の因果関係を明確化することが必要となるだろう。

さらに本研究で得られたデータを人間のデータと対応 づけ，より多様な課題に拡張していくことも必要である. 人間の行動とのデータに基づく対応が進展することで， 内発的動機づけに関するさらなる理解が進むとともに， それを支援する手段の開発に繫がると考える.

\section{$\S 2$ 知的好奇心による知識発見}

本研究における他の限界は，本研究が扱ったパターン マッチングの性質にある．本研究では現在の状況とマッ チするパスの発見という単純なパターンを扱った。プロ ダクションは現在の位置から特定の方向に向かうパスを, 現在地を変数として検索する。このプロダクションから の検索要求に対して，各時点で少数のパスのみが宣言的 モジュールからの検索候補になる。このような単純な状 況に対して，複雑な変数間の関係を含み，複数のマッチ ングを返すプロダクションルールの発火は，観察する人 間に驚きを生じさせることが指摘されている [森田 14]. こういった変数間の複雑な関係を含むパターンマッチン グは，領域間で知識を対応づける類推 [Gentner 83] と共 通するプロセスを含み，高い水準で人間の知的好奇心を 満たすと考えられる．これらを踏まえれば，今後，扱う パターンを複雑化し，複雑性に応じた報酬を付与するメ カニズムを検討することで，知的好奇心に駆動された知 識発見に関する議論を展開できると考える。

\section{$\$ 3$ 環境とのインタラクションを駆動する好奇心}

本研究のモデルは，事前にパターンマッチングの対象 となる宣言的記憶を与えられ，課題終了ルールに比べて 課題継続ルールが高いユーティリティを持つ状態からス タートした．これらより，本研究は，課題に対する好奇 心を既に有している状態からの減衰のプロセスを検討し たといえる.この設定は，本研究が扱った知的好奇心が， 自分の知識構造をより良い形にしたいという好奇心の認 知的側面 [Malone 81]，あるいはデータを圧縮することへ の欲求 [Schmidhuber 10] を扱うものであったことと整合 する。逆にいえば，好奇心の感覚的な側面 [Malone 81],
圧縮可能なデータを取得する欲求 [Schmidhuber 10] を扱 わなかった. 今後，これらのより低次な好奇心の側面を 扱うことで，外的な環境とのインタラクションを通した 宣言的記憶の獲得過程を検討できる.

さらに，外界からデータをモデルに取り込む仕組みを 構築することは，近年の深層強化学習における ICM (Intrinsic Curiosity Module [Aubret 19]) との接続に繋がる. 本研究で扱った Q-learning モデルと近年の深層強化学習 は，報酬を内部報酬と外部報酬に区別する点（式 (4) ）で 共通する。しかし，本研究が式 (5) に示す状態遷移の情 報量的なサプライズを内部報酬とするのに対し，ICM は ピクセル情報から得られるエージェントの次状態との予 測誤差を内部報酬とする。このように，従来の手法に対 して，近年の手法は外界の情報の変化に対する高精度の 予測をべースとする点で異なる. 本研究の Q-Learning モ デルにおいては，こういった外界の予測が不在であった め，行動の指向性が発生せず，局所的な探索の行動が強 化された可能性がある。

今後, 本研究で提案した ACT-R における好奇心のメ カニズムと上記のような先端的な深層強化学習の対応を 検討していくことで，人間および人工エージェントにお ける自律的な学習に関する理解が進展すると考える。

\section{$\diamond$ 参 考 文 献 $\diamond$}

[Alter 17] Alter, A.: Irresistible: The Rise of Addictive Technology and The Business of Keeping Us Hooked, Penguin, London (2017), （邦訳：上原裕美子訳：僕らはそれに抵抗できない「依存症ビジ ネス」のつくられかた，ダイヤモンド社（2019)）

[Anderson 04] Anderson, J. R., Bothell, D., Byrne, M. D., Douglass, S., Lebiere, C., and Qin, Y.: An integrated theory of the mind, Psychological Review, Vol. 111, No. 4, pp. 1036-1060 (2004)

[Anderson 05] Anderson, J. R.: Human symbol manipulation within an integrated cognitive architecture, Cognitive Science, Vol. 29, No. 3, pp. 313-341 (2005)

[Anderson 07] Anderson, J. R.: How Can the Human Mind Occur in the Physical Universe, Oxford University Press, New York (2007)

[Aubret 19] Aubret, A., Matignon, L., and Hassas, S.: A survey on intrinsic motivation in reinforcement learning, arXiv preprint arXiv:1908.06976 (2019)

[Bothell 19] Bothell, D.: ACT-R 7.13+ Reference Manual (2019)

[Brooks 86] Brooks, R.: A robust layered control system for a mobile robot, IEEE Journal on Robotics and Automation, Vol. 2, No. 1, pp. 14-23 (1986)

[Burda 18] Burda, Y., Edwards, H., Pathak, D., Storkey, A., Darrell, T., and Efros, A. A.: Large-scale study of curiosity-driven learning, arXiv preprint arXiv:1808.04355 (2018)

[Caillois 58] Caillois, R.: Les Jeux et les Hommes: Le Masque et la Vertige, Gallimard, Paris (1958), （邦訳：多田道太郎，塚崎幹夫 訳：遊びと人間，講談社（1990)）

[Csikszentmihalyi 90] Csikszentmihalyi, M.: Flow: The Psychology of Optimal Experience, Harper \& Row, New York (1990), （邦訳 : 今村浩明訳 : フロー体験一喜びの現象学一, 世界思想社 (1996))

[Dancy 15] Dancy, C. L., Ritter, F. E., Berry, K. A., and Klein, L. C.: Using a cognitive architecture with a physiological substrate to represent effects of a psychological stressor on cognition, Computational and Mathematical Organization Theory, Vol. 21, No. 1, pp. 90-114 (2015)

[Fodor 83] Fodor, J. A.: The Modularity of Mind, MIT Press, Cambridge (1983)

[Friston 10] Friston, K.: The free-energy principle: A unified brain 
theory?, Nature Reviews Neuroscience, Vol. 11, No. 2, pp. 127-138 (2010)

[Fu 06] Fu, W. and Anderson, J. R.: From recurrent choice to skill learning: A reinforcement-learning model, Journal of Experimental Psychology. General, Vol. 135, pp. 184-206 (2006)

[Gentner 83] Gentner, D.: Structure-mapping: A theoretical framework for analogy, Cognitive Science, Vol. 7, No. 2, pp. 155-170 (1983)

[Gonzalez 03] Gonzalez, C., Lerch, J. F., and Lebiere, C.: Instancebased learning in dynamic decision making, Cognitive Science, Vol. 27, No. 4, pp. 591-635 (2003)

[Huizinga 39] Huizinga, J.: Homo Ludens Versuch einer Bestimmung des Spielelementest der Kultur, Pantheon, Amsterdam (1939), （邦 訳：高橋英夫訳：ホモ・ルーデンス，中央公論新社（1973））

[Huys 16] Huys, Q. J., Maia, T. V., and Frank, M. J.: Computational psychiatry as a bridge from neuroscience to clinical applications, $\mathrm{Na}$ ture Neuroscience, Vol. 19, No. 3, pp. 404-413 (2016)

[Juvina 18] Juvina, I., Larue, O., and Hough, A.: Modeling valuation and core affect in a cognitive architecture: The impact of valence and arousal on memory and decision-making, Cognitive Systems Research, Vol. 48, pp. 4-24 (2018)

[Kahneman 11] Kahneman, D.: Thinking, Fast and Slow, Macmillan, New York (2011),（邦訳：村井章子 訳：ファストスロー(上，下) あなたの意思はどのように決まるか?，早川書房（2014））

[Koster 13] Koster, R.: Theory of Fun for Game Design, O'Reilly Media, Sebastopol (2013),（邦訳：酒井皇治 訳：「おもしろい」の ゲームデザイン一楽しいゲームを作る理論，オライリージャパ ン (2005))

[Kotseruba 18] Kotseruba, I. and Tsotsos, J. K.: 40 years of cognitive architectures: core cognitive abilities and practical applications, Artificial Intelligence Review, Vol. 53, pp. 17-94 (2018)

[Laird 17] Laird, J. E., Lebiere, C., and Rosenbloom, P. S.: A standard model of the mind: Toward a common computational framework across artificial intelligence, cognitive science, neuroscience, and robotics, AI Magazine, Vol. 38, No. 4, pp. 13-26 (2017)

[Lebiere 07] Lebiere, C., Gonzalez, C., and Martin, M.: Instancebased decision making model of repeated binary choice, in Proceedings of the 8th International Conference on Cognitive Modelling, pp. 67-72 (2007)

[Malone 81] Malone, T. W.: Toward a theory of intrinsically motivating instruction, Cognitive Science, Vol. 5, No. 4, pp. 333-369 (1981)

[Mnih 15] Mnih, V., Kavukcuoglu, K., Silver, D., Rusu, A. A., Veness, J., Bellemare, M. G., Graves, A., Riedmiller, M., Fidjeland, A. K., Ostrovski, G., et al.: Human-level control through deep reinforcement learning, Nature, Vol. 518, No. 7540, pp. 529-533 (2015)

[森田 14] 森田純哉, 三輪和久, 中池竜一, 寺井仁, 齊藤ひとみ, 小島 一晃, 神崎奈奈 : 意図せぬルールの発火に注目したプロダクショ ンシステムの学習支援, 教育システム情報学会誌, Vol. 31, No. 3, pp. 225-238 (2014)

[森田 20] 森田 純哉: 機械学習時代における認知的学習モデルの 役割 一 ACT-R による学習モデルの事例と支援システムへの搭 載—, 人工知能, Vol. 35, No. 2, pp. 223-233 (2020)

[Nagashima 20] Nagashima, K., Morita, J., and Takeuchi, Y.: Modeling intrinsic motivation in ACT-R : Focusing on the relation between pattern matching and intellectual curiosity, in Proceedings of the 18th International Conference on Cognitive Modelling, pp. 167-173, Applied Cognitive Science Lab (2020)

[Nagashima 21] Nagashima, K., Morita, J., and Takeuchi, Y.: Curiosity as pattern matching: Simulating the effects of intrinsic rewards on the levels of processing, in Proceedings of the 19th International Conference on Cognitive Modelling (2021)

[Pathak 17] Pathak, D., Agrawal, P., Efros, A. A., and Darrell, T.: Curiosity-driven exploration by self-supervised prediction, in International Conference on Machine Learning, pp. 2778-2787, PMLR (2017)

[Pink 11] Pink, D. H.: Drive: The Surprising Truth about What Motivates us, Penguin, London (2011), (邦訳 : 大前研一 訳：モチ ベーション 3.0 持続する「やる気!」をいかに引き出すか，講談 社 (2010))

[Reitter 10] Reitter, D. and Lebiere, C.: A cognitive model of spatial path-planning, Computational and Mathematical Organization Theory, Vol. 16, No. 3, pp. 220-245 (2010)

[Ritter 19] Ritter, F. E., Tehranchi, F., and Oury, J. D.: ACT-R: A cognitive architecture for modeling cognition, Wiley Interdisciplinary Reviews: Cognitive Science, Vol. 10, No. 3, p. e1488 (2019)

[Schmidhuber 10] Schmidhuber, J.: Formal theory of creativity, fun, and intrinsic motivation (1990-2010), IEEE Transactions on Autonomous Mental Development, Vol. 2, No. 3, pp. 230-247 (2010)

[Singh 05] Singh, S., Barto, A. G., and Chentanez, N.: Intrinsically motivated reinforcement learning, in Saul, L. K., Weiss, Y., and Bottou, L. eds., Advances in Neural Information Processing Systems 17, pp. 1281-1288, ress (2005)

[Sutton 98] Sutton, R. S. and Barto, A. G.: Reinforcement Learning: An Introduction, MIT Press, Cambridge (1998),（邦訳 : 三上貞芳, 皆川雅章訳：強化学習, 森北出版 (2000))

[Taatgen 03] Taatgen, N. A. and Lee, F. J.: Production compilation: A simple mechanism to model complex skill acquisition, Human Factors, Vol. 45, No. 1, pp. 61-76 (2003)

[寺尾 15] 寺尾 敦: 認知アーキテクチャの理論による脳の構造と 機能の解明, 電子情報通信学会誌, Vol. 98, No. 12, pp. 1083-1090 (2015)

[Turner 16] Turner, J. O., Nixon, M., Bernardet, U., and DiPaola, S.: Integrating Cognitive Architectures into Virtual Character Design, chapter Integrating ACT-R cognitive models with the unity game engine, pp. 35-64, IGI Global, Pennsylvania (2016)

[Vugt 18] Vugt, van M. K. and Velde, van der M.: How does rumination impact cognition? A first mechanistic model, Topics in Cognitive Science, Vol. 10, No. 1, pp. 175-191 (2018)

[Watkins 89] Watkins, C. J. C. H.: Learning from Delayed Rewards, $\mathrm{PhD}$ thesis, King's College, Cambridge (1989)

[Yerkes 08] Yerkes, R. M. and Dodson, J. D.: The relation of strength of stimulus to rapidity of habit-formation, Journal of Comparative Neurology and Psychology, Vol. 18, No. 5, pp. 459-482 (1908)

\section{〔担当委員：松島 裕康〕}

2021 年 2 月 22 日 受理

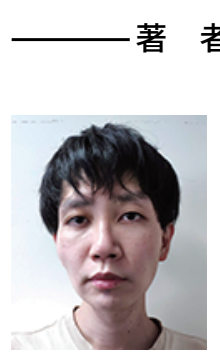

\section{紹 介}

\section{長島 一真(学生会員)}

2020 年静岡大学情報学部情報科学科卒業. 同年より同大 学院総合科学技術研究科情報学専攻修士課程纪在籍. 現在 に至る。認知モデルによる内発的動機づけのモデル化，お よびその応用に興味を持つ.

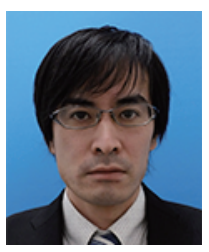

\section{森田 純哉(正会員)}

2006 年名古屋大学大学院人間情報学研究科博士課程修了. 博士 (学術). 北陸先端科学技術大学院大学知識科学研究科 助教, 名古屋大学未来社会創造機構特任助教を経て，2016 年より静岡大学情報学部准教授. 認知モデルの害世界応 用に関わる研究に従事する。目本認知科学会, ヒューマン インタフェース学会, 電子情報通信学会, 情報処理学会, Cognitive Science Society 各会員.

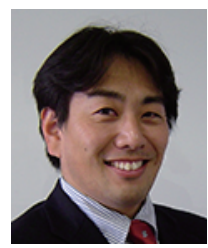

\section{竹内 勇剛(正会員)}

1999 年名古屋大学大学院人間情報学研究科博士課程修了. 博士 (学術)。1 1996 年より（株）国際電気通信基砧技術研 究所知能映像通信研究所研究員 (客員) を経て, 2001 年 静岡大学情報学部情報科学科講師。2015 年に同教授. 他 者や人工物，環境とのインタラクションを通した人間の認 知と行動に関わる研究に取り組んでいる. 日本認知科学会, ヒューマンインタフェース学会, 電子情報通信学会, 情報 処理学会, ACM 各会員. 